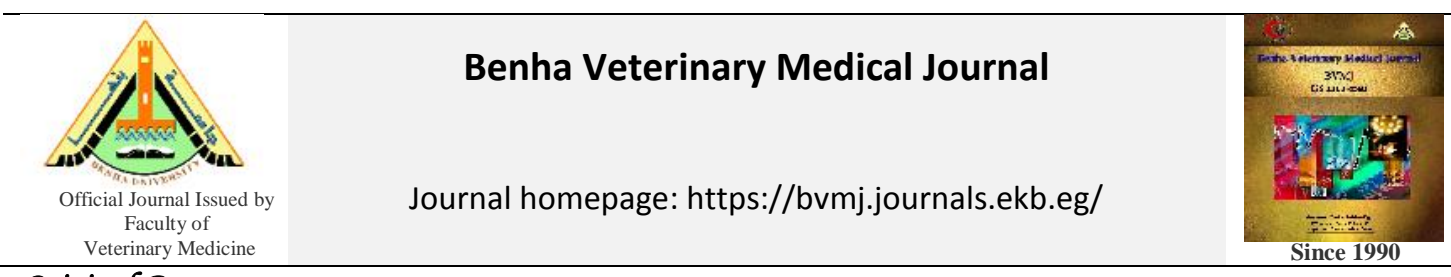

Original Paper

\title{
Isolation and Molecular Identification of Aspergillus species from Cultured Nile Tilapia (Oreochromis niloticus)
}

Ashraf A. Abd El Tawab ${ }^{1}$, Fatma I. El Hofy ${ }^{1}$, Eman M. Moustafa ${ }^{2}$, Marwa R. Halawa ${ }^{3}$

${ }^{I}$ Bacteriology, Immunology and Mycology Department, Fac. Vet. Med. Banha University.

${ }^{2}$ Department of Fish Diseases and Management, Faculty of Veterinary Medicine, Kafr El-Sheikh University, Kafr El-Sheikh governorate, Postal code: 33516, Egypt.

${ }^{3}$ Central Diagnostic and Research Lab Fac. Vet. Med. Kafrelsheikh Univ.

\section{ARTICLE INFO}

\begin{tabular}{l} 
Keywords \\
Aspergillus \\
Identification \\
Oreochromis niloticus \\
PCR. \\
\\
\hline Received 08/04/2020 \\
Accepted 19/04/2020 \\
Available On-Line \\
08/09/2020
\end{tabular}

\begin{abstract}
The present study was carried out on 120 examined cultured Nile tilapia, Oreochromis niloticus (O. niloticus) ( 80 diseased fish and 40 apparently healthy) were collected alive from private fish farms at Kafr El Sheikh Governorates from April to October 2018. Grossly, examined diseased $O$. niloticus revealed eroded fins, redness on the skin, congested protruded anal opening and sometimes darkness on skin, ulcers with different sizes, and eye turbidity especially in fish naturally infected with Aspergillus, Fusarium and Pencillium. Mycological examination revealed isolation of 7 Genera of fungi from total incidence of 300 fungal isolates; 240 fungal isolates from diseased $O$. niloticus and 60 isolates from apparently healthy one. Aspergillus flavus and Aspergillus niger were the most predominant fungi isolated from either apparently healthy or even diseased one mainly from internal organs. Molecular identification was performed using inter-transcriped spacer (ITS) gene for $A$. flavus and A. niger. Developed PCR assay specific primer detect A. flavus and A. niger showing clear bands at 595 and $600 \mathrm{bp}$ molecular weight, respectively.
\end{abstract}

\section{INTRODUCTION}

Fish serves as the most significant source of human dietary protein around the world, particularly in African countries (Hussain et al., 2011). Natural fisheries are powerfully depleted, and the aquaculture end up basic plans to repay the need; providing a significant and principal protein source for human utilization (Mohamed et al., 2017). Aquaculture constitutes the greater part of the total fish production in the world and about $77 \%$ of the absolute Egyptian fish production (Mur, 2014 and FAO, 2016).

Nile tilapia (Oreochromis niloticus) is seen as a widely cultured species amongst the most pervasive freshwater fishes in Egypt as a result of their fast growth rate with great meat quality, marketable request, protection from illnesses and capacity to withstand unfavorable ecological conditions (Dawood et al., 2019 a, b).

The expansion of the aquaculture industry is exposed to a few biological stressors (Awad \& Awaad, 2017). It was investigated that illness is a last result of a complex collaboration of the host, its condition and the pathogen itself where the ecological pressure is seen as an important actuating component viewed as a vital initiating element causing different diseases (El-Deep et al., 2019). Unfavorable aquaculture conditions can upgrade fish diseases transmission, particularly contagious fungal diseases, leading to decreased fish production and further economic losses (Ashour et al., 2017).

Fungal infections in fish are seen as secondary reason for infection; fungi influencing fishes are opportunistic and assault the fishes just in the event that they are pushed or invulnerable bargained. Essential primary causes may be ascribed to temperature change, water quality issues, poor conditions, skin injury because of trauma or excessive handling, bacterial and/or parasitic diseases (Chauhan et al., 2014).

The most well-known widely recognized contagious fungal infection was the pathogenic oomycetes; which belong to the order Saprolegniales, including the genera Saprolegnia, Achlya and Aphanomyces. Saprolegniosis has noteworthy effect on freshwater biological systems by infecting different host organisms and their eggs (Ruthig, 2009; Eissa et al., 2013; Bassiouny et al., 2019).

Aspergillus sp. causes systematic diseases with high mortality rates in fish, whereby the diseases mostly occur through fish feed pollution (Urquhart et al., 2016) and the pathogenesis of Aspergillus fumigatus and Aspergillus niger have been accounted in freshwater fishes by Chauhan (2013).

The present study was carried out to shed light on the isolation and molecular identification of Aspergillus sp. among cultured Nile tilapia (Oreochromis niloticus) in Kafrelsheikh private fish farms.

\section{MATERIAL AND METHODS \\ 2.1. Fish}

A total number of 120 examined cultured $O$. niloticus $(80$ diseased fish and 40 apparently healthy) were collected alive from private fish farms at Kafr El Sheikh Governorates from April to October 2018. The samples

* Corresponding author: Eman Moustafa Moustafa, Department of Fish Diseases and Management, Faculty of Veterinary

Medicine, Kafr El-Sheikh University, Kafr El-Sheikh governorate, Postal code: 33516, Egypt. emantarek2002@yahoo.com 
were collected with average body weight of $40 \pm 5 \mathrm{~g}$. Alive fish were transported in double polyethylene bags; with $1 / 2$ of its volume water pumped with pressured oxygen to the wet lab. of Fish Diseases and Management Department, Faculty of Veterinary Medicine, Kafr El-Sheikh University, Egypt and kept in well-prepared glass aquaria provided with adequate amounts of dechlorinated water with consistent aeration (Langdon \& Jones, 2002).

\subsection{Clinical \& Postmortem examination}

All collected fish were clinically examined to recognize any clinical abnormalities following McVicar (1982). Postmortem assessment of the internal organs was completed on sacrificed and freshly dead fish according to Austin \& Austin (2012).

\subsection{Mycological examination:}

2.3.1. Isolation of the fungus from diseased $O$. niloticus:

Mycological examination was carried out according to Noga, (1993). Specimens were taken from fish showing skin lesions under complete aseptic condition utilizing sterile dissecting needle from the skin, gills and internal organs (liver, kidneys) and inoculated into Sabaroud's dextrose agar (SDA) medium plates with expansion of chloramphenicol (CID) $50 \mathrm{mg} / \mathrm{mL}$; to inhibit bacterial growth; and incubated at room temperature for 7-10 days (Whitman, 2004). All the positive molds cultures were purified by sub culturing on SDA plates. The mold growth was inspected for gross and micro morphological characteristics according to Collins \& Lyne (1984).

\subsubsection{Identification of different molds}

Identification the morphological characters of plates including growth appearance of the cultures, rate of growth, texture and color of the surface and reverse side colonies according to Refai et al., (2010). Preliminary recognition of molds was accomplished using wet mount preparation. A little bit of fungal growth was placed on a glass slide with drop of distilled water, the mycelial mass was gently teased a part with two dissecting needles, covered with a clean cover slide and inspected under the microscope.

The confirmatory identification was conducted utilizing the method described by Bassiouny et al. (2019). Briefly, a drop of lactophenol cotton blue dye was set on a clean glass slide; a portion of the fungal culture was transferred into the lactophenol cotton blue dye and teased with a 22 -gauge nichrome needle to separate the hyphae. The coverslip was placed on the preparation and inspected under low and high-power magnification with reduced light for identification using the microscope model Leica, Germany. Microscopic characteristic of fungi such as hyphae, conidial heads and arrangements of conidia were watched.

\subsection{Molecular identification for molds}

Genomic DNA was extracted from a pure culture of fungal isolates using the DNA extraction Kit (Qiagen, Hilden, Germany) following the manufacturer's guidelines. Fungal colonies were inoculated into SD broth and incubated at room temperature for 7-10 days; then $55 \mathrm{mg}$ from cultured mycelium was centrifuged at 300xg for 5 minutes. Mycelia were washed with sterile phosphate buffered saline (PBS). 201 proteinase $\mathrm{K}$, buffer AL vortex and ethanol (96$100 \%$ ) vortex were added and centrifuged at $>6000 \times \mathrm{g}$ (8000rpm) for $1 \mathrm{~min}$. Buffer AW1 was included and centrifuged at $>6000 \times \mathrm{g}(8000 \mathrm{rpm})$ for $1 \mathrm{~min}$ and buffer
AW2 was included and centrifuged for $3 \mathrm{~min}$ at 20,000xg $(14,000 \mathrm{rpm})$. The spin column was transferred to a new 2 $\mathrm{ml}$ micro centrifuge tube. DNA was eluted by adding 200

1 buffer AE to the center of the spin column membrane, incubated for $1 \mathrm{~min}$ at room temperature (15-25 C) and centrifuged for $1 \mathrm{~min}$ at $>6000 \times \mathrm{g} \quad(8000 \mathrm{rpm})$. Oligonucleotide primers were planned according to White et al. (1990) for amplification of the ITS.

ITS1 (5' TCCGTAGGTGAACCTGCGG 3')

ITS4 (5' TCCTCCGCTTATTGATATGC 3')

To amplify the DNA, a PCR reaction was set up by including $6 \mu \mathrm{L}$ of extracted DNA, $1 \mu \mathrm{L}$ of forward and reverse primers ( $20 \mathrm{pmol}), 12.5 \mu \mathrm{L}$ Emerald Amp GT PCR master mix (2x premix)and sterile water up to a final volume of $25 \mu \mathrm{L}$. The PCR reaction was done in thermal cycler (Eppendorf, Hauppauge, New York) and incorporated an initial cycle at $94^{\circ} \mathrm{C}$ for 5 min, trailed by 35 cycles at $94^{\circ} \mathrm{C}$ for $30 \mathrm{sec}, 56^{\circ} \mathrm{C}$ for $40 \mathrm{sec}, 72^{\circ} \mathrm{C}$ for 50 $\mathrm{sec}$, and a final prolongation step of $72^{\circ} \mathrm{C}$ for $10 \mathrm{~min}$. Consequently, PCR amplicons were isolated and investigated by gel electrophoresis by loading products onto a $1.5 \%$ agarose gel supplemented with $1 \%$ ethidium bromide (50 $\mathrm{ng} / \mathrm{mL})$ and picturing bands using an ultraviolet lamp at a wavelength of $300 \mathrm{~nm}$.

\section{RESULTS AND DISCUSSION}

Mycotic diseases of fish are a genuine risk to the sustainability of aquaculture industry. The expanding recurrence of invasive fungal infection and the high mortality associated with dispersed fungal diseases have featured the requirement for quick identification of infectious molds from clinical samples.

1. Clinical \& Postmortem examination

In the current study, the general signs of the clinically diseased $O$. niloticus appeared as eroded fins, redness on skin, congested protruded anal opening and sometimes darkness on skin, ulcers with different sizes, and eye turbidity. The ulcerative areas over the skin and fins erosion might be expected to the lytic action of primary bacterial infection as all fungal infections are considered as secondary invader pathogen; these results concurred with many authors (Chauhan, 2014 and Bassiouny et al., 2019). Redness on the skin may be attributed to the extracellular products of molds resulting in severe symptomatic changes that appear on the fish in the form of hemorrhagic patches; the result agreed with (Bassiouny et al., 2019) where hemorrhagic patches was observed in both examined diseased Nile tilapia and African catfish. Regarding the postmortem lesions, enlarged liver with moderate hemorrhagic spots were the most characteristic. This result may be ascribed to either the fact that most mycotic diseases are secondary invaders following fundamental systemic bacterial infection which is responsible mainly for this internal lesions and/or because of extracellular products produced by fungi that meddle with capacity of liver leading to congestion in internal organs particularly liver (El-Atta, 2008; Mohamed et al., 2017; Bassiouny et al., 2019 and Abd El Tawab et al., 2020).

2. Mycological examination

Mycological examination revealed the isolation of 300 fungal isolates; 240 and 60 isolates from $80 \mathrm{O}$. niloticus showing clinical signs and 40 apparently healthy $O$. niloticus, respectively from skin, gills, liver and kidneys (Table 1A \& B). The high recurrence of mould isolates was in $O$. niloticus showing clinical signs; the result 
agreed with Refai et al. (2010) and Bassiouny et al.

(2019).

Table 1A Incidence of molds isolated from different organs of diseased $O$. niloticus

\begin{tabular}{|c|c|c|c|c|c|}
\hline \multirow[t]{2}{*}{ Molds } & & Skin \& Fins & Gills & Liver & Kidneys \\
\hline & No. & No. & No. & No. & No. \\
\hline Aphanomyces sp. & 8 & 8 & 0 & 0 & 0 \\
\hline Asperigillus flavus & 58 & 0 & 10 & 28 & 20 \\
\hline Asperigillus niger & 43 & 0 & 9 & 8 & 26 \\
\hline Pencillium sp. & 27 & 11 & 7 & 9 & 0 \\
\hline Fusarium sp. & 37 & 0 & 25 & 0 & 12 \\
\hline Mucor $s p$. & 30 & 15 & 9 & 6 & 0 \\
\hline Alternaria $s p$. & 37 & 0 & 0 & 22 & 15 \\
\hline Total & 240 & 34 & 35 & 98 & 73 \\
\hline
\end{tabular}

Table 1B Incidence of Molds isolated from different organs of apparently healthy. O. niloticus

\begin{tabular}{|c|c|c|c|c|c|}
\hline \multirow[t]{2}{*}{ Molds } & & in \& Fins & Gills & Liver & Kidney \\
\hline & No. & No. & No. & No. & No. \\
\hline Aphanomyces sp. & 2 & 2 & 0 & 0 & 0 \\
\hline Asperigillus flavus & 20 & 0 & 0 & 12 & 8 \\
\hline Asperigillus niger & 15 & 0 & 2 & 8 & 5 \\
\hline Pencillium sp. & 3 & 3 & 0 & 0 & 0 \\
\hline Fusarium sp. & 7 & 0 & 7 & 0 & 0 \\
\hline Mucor sp. & 8 & 3 & 4 & 1 & 0 \\
\hline Alternaria sp. & 5 & 5 & 0 & 0 & 0 \\
\hline Total & 60 & 13 & 13 & 21 & 13 \\
\hline
\end{tabular}

A. flavus was the predominant among both diseased and healthy $O$. niloticus while Aphanomyces $s p$. was the most reduced isolates. This result disagrees with Bassiouny et al. (2019) where they recorded that A. flavus was the predominant among apparently healthy $O$. niloticus only. This might be credited to variable host susceptibility due to topographical distribution. However, the result is coincided with that reported by Abd El-Tawab et al. (2020).

3. Orphological identification of isolated molds

The morphological recognizable proof of molds revealed the presence of different moulds including: Aphanomyces sp., Aspergillus flavus; Aspergillus niger; Penicillium sp.; Fusarium sp., Mucor $s p$. and Alternaria $s p$. The most predominant isolated fungi was A. flavus among both diseased and healthy $O$. niloticus while Aphanomyces sp. was the most reduced isolates.

Strangely, Aspergillus species showed some variety inside similar genus. Aspergillus flavus (A. flavus) seemed smooth with several aerial growths; the shading changes from yellow to yellowish green by maturing; while microscopically, the conidiophores were long and harsh, the vesicles were rounded and huge and the stigmata were biseriate, loose, and radiate giving rise to ovoid rough conidia (Fig. 1).

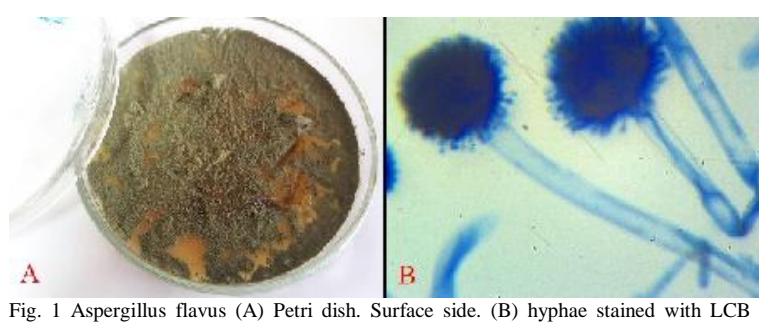

Colonies of Aspergillus niger (A. niger) had dark shading with emanated edges with wooly surface, while microscopically had incredibly long, smooth and yellowish conidiophores, vesicles were extremely huge and globes while the stigmata were biseriate, compact and radiate and the conidia were globes and smooth (Fig. 2). The highest incidence within organs was observed to be in liver in most of Aspergillus sp. This may support the fact that Aspergillosis is a systemic disease. The result is similar to some previous papers (Diab, 2010; Refai et al., 2010 and Abd El-Tawab et al. 2020).
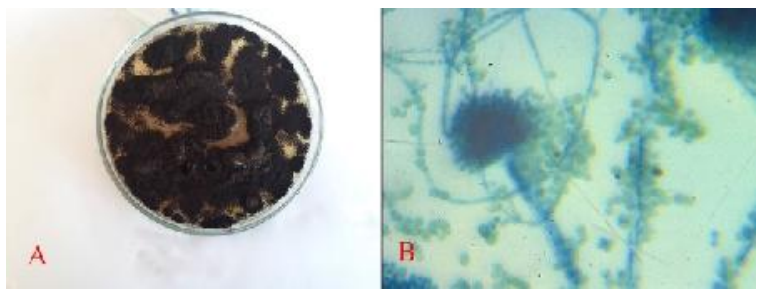

Fig. 2 Aspergillus niger (A) Petri dish Surface side. (B) hyphae stained with LCB showing characteristic round head with black conidia

\section{Molecular identification}

Molecular identification (Polymerase Chain Reaction) using inter-transcribed spacer (ITS) gene, which is a universal gene, is one of the most significant ways to deal with various fungal infections (Eissa et al., 2013). Accordingly, in the current study, molecular identification was performed using ITS gene for the most prevalent isolates among either diseased or apparently healthy fish. Two isolates of Aspergillus flavus and Aspergillus niger isolates were used. Developed PCR assay specific primer detect not only Aspergillus flavus demonstrating a clear band at 595 bp molecular weight (Fig. 3), but also Aspergillus niger showing clear bands at $600 \mathrm{bp}$ molecular weight, respectively (Fig. 4). The current acquired outcome is actually like Henry et al., (2000) where Aspergillus flavus and Aspergillus niger delivered a reasonable band at $595 \mathrm{bp}$ and $599 \mathrm{bp}$, respectively. These variations may be attributed to various tested primers sequences and PCR protocol as a result of the different amplification cycles (Afzali et al., 2015 and Youssef, 2017). 


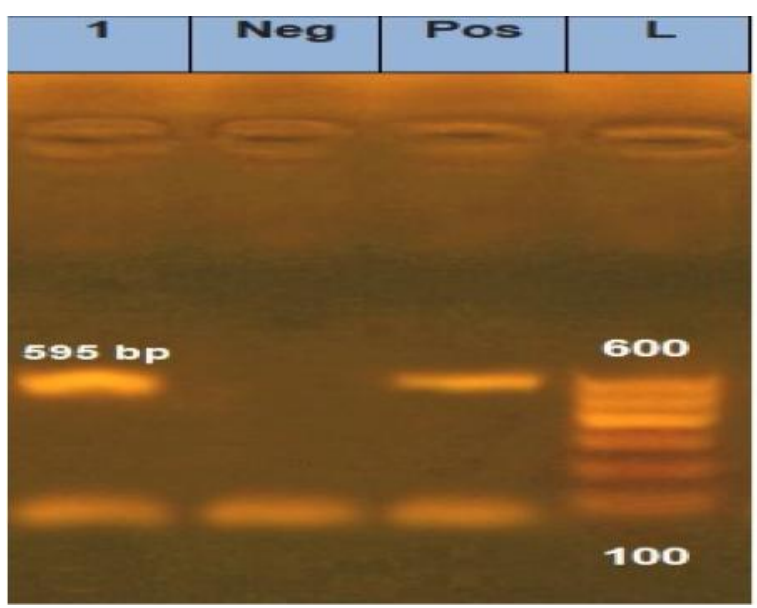

Fig. 3 Agarose gel electrophoresis for PCR products representing amplification of $595 \mathrm{bp}$ of inter-transcribed spacer (ITS) gene in Aspergillus flavus. Lane 1: 100 bp DNA Ladder. Pos. : is control positive. Neg.: is control Negative. 1: positive sample for Asperigillus flavus

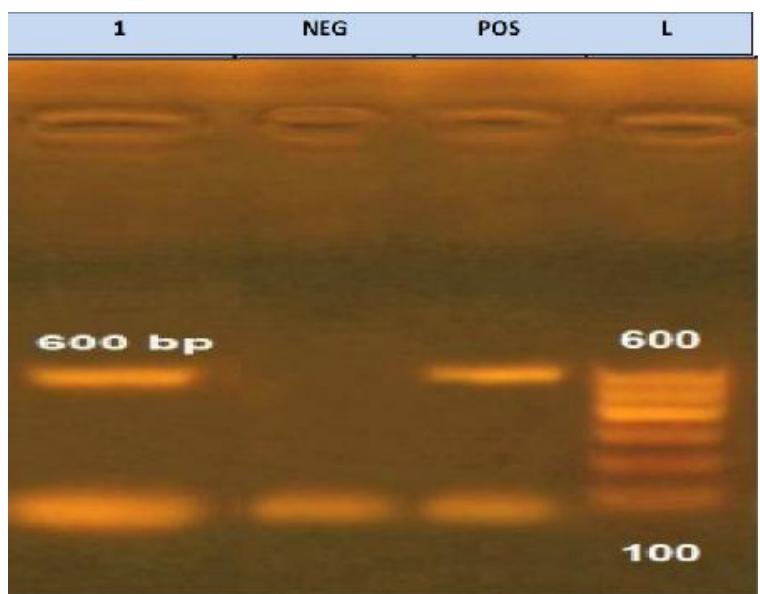

Fig. 4 Agarose gel electrophoresis for PCR products representing amplification of $600 \mathrm{bp}$ of inter-transcribed spacer (ITS) gene in Aspergillus niger. Lane 1: 100 bp DNA Ladder. Pos. : is control positive. Neg.: is control Negative. 1: positive sample for Aspergillus niger

\section{CONCULSION}

From the current study, it could be presumed that Aspergillus flavus, Aspergillus niger could be isolated from both clinically diseased and apparently healthy $O$. niloticus mainly from internal organs supporting the fact that Aspergillosis is a systemic disease. Briefly, although most fungi are considered to be typical mycoflora, but they still can cause infections to fish. Therefore, it is suggested that proper health management practices should be adapted while rearing fish, so that the chances of fungal infection can be limited.

\section{REFERENCES}

1. Abd El Tawab, A. A., El Hofy, F. I., Moustafa, E. M. and Halawa, M. R. (2020). Insight into Isolation, Identification and Antimicrobial Sensitivity of some Moulds Isolated from Fresh Water Fishes. Advances in Animal and Veterinary Sciences. 8 (2):174-182.

2. Afzali, F., Duad, H. H. M., Shankar, S., Khan, M. S. and Afzali, S. (2015). Detecting Aphanomyces invadans in Pure Cultures and EUS-infected Fish Lesions by Applying PCR. Malays. J. Med. Boil. Res. Vol. 2. No. 2.

3. Ashour, A. A., Mustafa, S. A. and Yassein, S. N. (2017). Histopathological studies on common carp (Cyprinus carpio L.) infected with Saprolegnia sp. and treated with Virkon ${ }^{\circledR}$
Mirror Res. Vet. Sci. Anim. 6:19-30

4. Austin, B. and Austin, D. A. (2012). Bacterial fish pathogens; diseases of farmed and wild fish. Springer, New York, London.

5. Awad, E. and Awaad, A. (2017). Role of medicinal plants on growth performance and immune status in fish. Fish \& Shellfish Immunology. 67: 40-54

6. Bassiouny, N. B., Moustafa, E. M., Kassab, M. M. and Marzouk, W. H. (2019). Seasonal Screening of the Mycotic Infections of Cultured Freshwater Fishes in Kafr El-Sheikh Governorate. Slov. Vet. Res. 56 (Suppl 22): 321-331.

7. Chauhan, R. (2013). Studies on conidial fungi isolated from some freshwater fishes. International Journal of Advanced Life Sciences (IJALS). 6 (4):131-135.

8. Chauhan, R. (2014). Studies on some freshwater fishes found infected with dermatomycoses, collected from different water bodies in and around Bhopal, India. Indo Am. J. Pharm. Res., 4: 1591-1596.

9. Chauhan, R., Lone, S. and Beigh, A. H. (2014). Pathogenicity of three species of Aspergillus (A. fumigatus, A. niger \& A. sydowii) on some freshwater Fishes. Life Sci Leaflets.14:65-72.

10. Collins, C. H. and Lyne, P. M. (1984). Microbiological Methods. Edn 5, Butterworth's \& Co. Publishers, Ltd.

11. Dawood, M. A., Shukry, M., Zayed, M. M., Omar, A. A., Zaineldin, A. I. and El- Basuini, M. F. (2019a). Digestive enzymes, immunity and oxidative status of Nile tilapia (Oreochromis niloticus) reared in intensive conditions. Slov. Vet. Res. 56 (Suppl 22): 99-108.

12. Dawood, M. A. O., Eweedah, N. M., Moustafa, E. M. and Shahin, M. G. (2019b). Synbiotic effects of Aspergillus oryzae and beta-glucan on growth and oxidative and immune responses of Nile tilapia, Oreochromis niloticus. Probiotics and Antimicrobial Proteins. (In press)

13. Diab, A.M.A. (2010): Studies on some systemic mycotic affection in cultured freshwater fish $\mathrm{Ph} . \mathrm{D}$. Thesis (Fish diseases and hygiene), Faculty Vet. Med., Alexandria university.

14. Eissa, A. E., Abdelsalam, M., Tharwat, N. and Zaki, M. (2013). Detection of Saprolegnia parasitica in eggs of angelfish Pterophyllum scalare (Cuvier-Valenciennes) with a history of decreased hatchability. Int. J. Vet. Sci. Med. 1: 714.

15. El-Atta, M. E. A. (2008). Saprolegniosis in freshwater cultured Tilapia nilotica (Orechromis niloticus) and trial for control by using Bafry D50/500. Proceedings of the $8^{\text {th }}$ International Symposium on Tilapia in Aquaculture, October 12-14, 2008, Cairo, Egypt. 1403-1418.

16. El-Deep, M. H., Dawood, M. A. O., Assar, M. H., Ijiri. D. and Ohtsuka, A. (2019). Dietary Moringa oleifera improves growth performance, oxidative status, and immune related gene expression in broilers under normal and high temperature conditions. Journal of Thermal Biology. 82:157163.

17. FAO. (2016). Fishery and Aquaculture Statistics Yearbook 2014. Rome, Italy: Food and Agriculture organization of the United Nations. ISSN 2070-6057.

18. Henry, T., Iwen, P. C. and Hinrichs, S. H. (2000). Identification of Aspergillus Species Using Internal Transcribed Spacer Regions 1 and 2. J. Clinical Microbiol. 38(4): 1510-1515.

19. Hussain, S. M., Javed, M., Javid, A., Javid, T. and Hussain, N. (2011). Growth responses of Catla catla, Labeo rohita and Cirrhina mrigala during chronic exposure of iron. Pak J Agric Sci. (1): 48: 225-230

20. Langdon, J. and Jones, B. (2002). Design and implementation of health testing protocols for fish with special reference to sample size, test sensitivity and specifity, predictive value and risk, Australian Standard Diagnostic Techniques for Fish Diseases.

21. McVicar, A. H. (1982). Ichthyophonus infections of fish. In Roberts RJ (ed) Microbial diseases of fish. Academic Press. London. Pp. 243-269.

22. Mohamed, H. M., Emeish, W. F., Braeuning, A. and Hammad, S. (2017). Detection of aflatoxin-producing fungi 
isolated from Nile tilapia and fish feed. EXCLI journal, 16:1308-1318.

23. Mur, R. (2014). Development of the aquaculture value chain in Egypt. Report of the National Innovation Platform Workshop, Cairo, 19-20 February 2014. Cairo: World- Fish. An Industry Assessment of Tilapia Farming in Egypt.

24. Noga, E. J. (1993). Fungal and algal disease of temperate freshwater and estuarine fishes, in Stoskopf MK (ed). Fish Medicine. Philadelphia, PA, Saunders. Pp. 278-283.

25. Refai, M. K., Laila, K., Amany, M. and Shimaa, E. S. (2010). The assessment of Mycotic settlement of freshwater fishes in Egypt. J Am Sci. 6(11): 823-831.

26. Ruthig, G. R. (2009). Water molds of the genera Saprolegnia and Leptolegnia are pathogenic to the North American frogs Rana catesbeiana and Pseudacris crucifer, respectively. Dis Aquat. Org. 84:173-178.
27. Urquhart, K., Collins, C., Monte, M., Sokolowska, J., Secombes, C. and Collet, B. (2016). Individual measurement of gene expression in blood cells from Rainbow trout Oncorhynchus mykiss (Walbaum). J. Exp. Applied Animal Sci. 2(1):1-9.

28. White, T. J., Bruns, T., Lee, S. and Taylor, J. (1990) Amplification and direct sequencing of fungal ribosomal RNA genes for phylogenetics. PCR Protocols: A Guide to Methods and Applications. 18(1):315-322.

29. Whitman, K. A. (2004). Finfish and Shellfish Bacteriology Manual; Techniques and Procedures. ISBN 0-8138-1952-0 Iowa State Press.

30. Youssef, H. A. (2017). Studies on Aphanomycosis in Fresh water African catfish. M. V. Sc. Thesis. Fish Diseases and management Dept., Fac. Vet. Med., Benha Univ. 